\title{
Climate change and health: impacts, vulnerability, adaptation and mitigation
}

\author{
Tord Kjellstrom ${ }^{\mathrm{A}, \mathrm{B}}$ and Haylee J. Weaver ${ }^{\mathrm{A}}$ \\ ${ }^{\mathrm{A} N a t i o n a l ~ C e n t r e ~ f o r ~ E p i d e m i o l o g y ~ a n d ~ P o p u l a t i o n ~ H e a l t h, ~}$ \\ Australian National University \\ ${ }^{\mathrm{B} C o r r e s p o n d i n g ~ a u t h o r . ~ E m a i l: ~ k j e l l s t r o m t @ y a h o o . c o m ~}$
}

\begin{abstract}
Global climate change is progressing and health impacts have been observed in a number of countries, including Australia. The main health impacts will be due to direct heat exposure, extreme weather, air pollution, reduced local food production, food- and vectorborne infectious diseases and mental stress. The issue is one of major public health importance. Adaptation to reduce the effects of climate change involves many different sectors to minimise negative health outcomes. Wide-scale mitigation is also required, in order to reduce the effects of climate change. In addition, future urban design must be modified to mitigate and adapt to the effects of climate change. Strategies for mitigation and adaptation can create co-benefits for both individual and community health, by reducing non-climate-related health hazard exposures and by encouraging health promoting behaviours and lifestyles.
\end{abstract}

Since 1950, average land temperatures in Australia have risen by $0.9^{\circ} \mathrm{C} .{ }^{1} \mathrm{~A}$ decline in rainfall has been observed for much of eastern and south-western Australia, whereas north-western Australia has experienced wetter summers. ${ }^{1}$ Globally, the trend of climatic variability is similar. ${ }^{2}$

The process will continue with a projected average global temperature increase of 1.8 to $4.0^{\circ} \mathrm{C}$ (average $3^{\circ} \mathrm{C}$ ) by 2100 depending on actions taken to limit greenhouse gas (GHG) emissions and scenarios for future development. ${ }^{2}$ Rainfall is likely to become more variable and there will be more extreme weather with storms, floods and droughts. ${ }^{2}$ By 2030 the average temperature in Australia may increase by $1^{\circ} \mathrm{C}$, and by 2070 , it may have increased by $1.8^{\circ} \mathrm{C} .{ }^{1}$ Decreases in rainfall are predicted for southern areas in winter, and for eastern areas in spring, while Australian average rainfall may not change. ${ }^{1}$ It is essential that the Australian community is adequately prepared for any health consequences of climate change. ${ }^{3}$

\section{Adaptation and mitigation}

Australia has diverse environments including alpine, temperate, tropical and desert. There are numerous low population density rural areas and highly populated cities. The possible health impacts of climate change for people living in each type of area need to be considered when developing strategies to manage climate change.

The aim of mitigation is to reduce anthropogenic GHG emissions and other causes of climate change, for instance, by increasing electricity generated from renewable sources (hydro-electric, solar and wind energy) and reducing motor vehicle use. In addition, reduction of meat consumption is considered a mitigation strategy, due to the energy-intensive methods of modern farming and methane emissions from cows and sheep. ${ }^{4}$ Mitigation strategies are often integrated into planning and infrastructure by local councils and state and federal governments; however, individuals can also participate on a small scale by reducing unnecessary energy consumption and using cars less frequently.

Adaptation means modifying current policy and practice to cope with unavoidable changes in climate. Governments need to implement community-wide adaptation plans, while individuals can act in a number of ways; for example, by staying in the shade while outside, or installing ceiling fans to reduce the risk of direct heat effects. ${ }^{5}$ Mitigation and adaptation strategies can have cobenefits for health. For example, a reduction in car use reduces GHGs as well as decreasing crash injuries, air pollution and traffic noise and increasing personal physical activity and fitness levels. ${ }^{6}$

\section{Coping with health impacts of climate change in Australia}

The expected changes in the climate may lead to several types of increased mortality and morbidity, including temperature-related illness and death, extreme weather effects, air pollution effects, water and food-related diseases, vectorborne diseases, effects of food and water 
shortages and effects of population displacement. ${ }^{7,8}$ Although the most severe health impacts are expected in low income countries, Australia will not be spared (see for example, http://www.environment.nsw.gov.au/ climatechange/health.htm). ${ }^{7-9}$ The people most vulnerable to the effects of climate change are children, elderly people, Indigenous communities and people with preexisting diseases and disabilities.

\section{Environmental disasters, storms and floods}

Storms, droughts and other climatic disasters are likely to increase in intensity and frequency (albeit with regional variation). ${ }^{10}$ Regional, targeted preparation plans for the health sector are therefore necessary. Tropical cyclones and other storms will cause injuries and flooding due to storm surges and severe downpours. ${ }^{11}$ Storms create the risk of drowning and health risks from damaged water supplies, sewage pipes, loss of electricity and contaminated food. The harmful effects of storms were demonstrated in the Hunter region of New South Wales (NSW) in 2007.12 Problems with water and sewerage supply and quality were experienced because pumps failed. Food was spoiled as it could not be cooked properly or kept cool in refrigerators, due to problems with electricity supply. ${ }^{12}$ Floods can also lead to increased infectious and vectorborne diseases. ${ }^{13}$ Adaptation to storms requires preventive steps, including timely storm warnings and long-term seasonal modelling of the future frequency of storms.

\section{Extreme heat exposure}

Heat waves can dramatically increase mortality as seen in France in 2003. ${ }^{14}$ For Australia, models project more hot days (temperatures greater than 35 to $40^{\circ} \mathrm{C}$ ) by 2070 , while the frequency of cold spells will decrease. ${ }^{1}$ Heat exposure causes morbidity and mortality, particularly in urban areas due to the heat island effect. ${ }^{15,16}$ Research in five major Australian cities showed that mortality increased at temperatures above $28^{\circ} \mathrm{C}$, particularly among people 65 years or older. ${ }^{17-20}$ In NSW, hospital admissions for heat-related illnesses increased during heat waves. In Adelaide, overall daily mortality has not increased during heat waves, but ambulance emergencies and certain types of hospital admissions (for instance, mental health categories) have increased. ${ }^{21}$ Heat wave warning systems and response plans are needed in addition to housing, workplace and urban design that maximises natural breezes and shade and minimises the heat island effect. ${ }^{20}$

A particular risk in hot weather in Australia is bush fires and related health risks from smoke and burns. ${ }^{22}$ Adaptive strategies for fires involve reducing fire risk by controlled burning of fuel in fire-prone forests and fire warning systems.

\section{Heat stress and workforce productivity}

Heat can cause physiological stress, particularly in people with high levels of physical activity. ${ }^{23}$ Children and elderly people are also vulnerable to heat stress as their physiology is less resilient than that of younger adults and they may be less able to take cooling action in heat waves. ${ }^{24}$ Australian studies have primarily measured exposure and physiological effects in workers with extreme heat exposure, such as fire fighters, mine workers, sheep shearers, and cattle musterers. ${ }^{25-31}$ Direct heat exposure reduces a worker's ability to continuously carry out heavy physical work. International standards recommend adequate rest breaks in hot environments. ${ }^{32-35}$ Heat exposure also limits the ability of people to exercise for leisure and health. ${ }^{36}$

\section{Water quality and quantity}

Intense precipitation events can overload sewers and storm-water drains and flush pathogens from catchment areas into drinking water reservoirs and dams. ${ }^{37}$ Drought can concentrate pollutants in dams, via evaporation, and increased water temperature in dams and lakes can lead to blooms of toxin-producing cyanobacteria. ${ }^{38}$ Modelling can be used to predict pathogen loads in water supplies, which may be a useful tool in managing drinking water supplies in the future, when climate change influences water quality and availabilty. ${ }^{39}$ Desalination plants, and improved water recycling may contribute to water security. Adaptive strategies for reducing water consumption are already in place in most councils and shires in Australia in order to conserve the water currently held in dams.

\section{Air pollution}

Epidemiological studies in Australian cities have documented increased daily mortality and hospital admissions associated with urban air pollution. ${ }^{40,41}$ More ozone is formed from the exhaust emissions of motor vehicles during summer periods of increasing heat in combination with strong sunlight. ${ }^{42}$ During the heat wave in France in 2003, the attributable fractions of daily mortality excess due to heat and ozone exposure were similar. ${ }^{43}$ Many excess deaths may have been caused by ozone and not by heat itself. The effects of particulate matter air pollution in Brisbane have been shown to increase alongside temperature. ${ }^{44} \mathrm{~A}$ reduction in car usage, to reduce emissions of GHGs and other air pollutants such as particulate matter and nitrogen dioxide, is a key mitigation strategy. ${ }^{40}$

Pollen and other aeroallergens, such as mould spores, may be influenced by climate change, increasing asthma risks. ${ }^{45}$ Pollen warnings and individual management of asthma are two adaptive strategies that can reduce respiratory diseases affected by aeroallergens.

\section{Vectorborne infectious diseases}

The potential risk of increased vectorborne disease spread in Australia due to climate change was first discussed a decade ago. ${ }^{46,47}$ Distributions of most arboviruses may alter due to climate change, but those that are highest in prevalence in Australia are Ross River virus (RRV), 
Barmah Forest virus (BFV) and dengue virus. ${ }^{13}$ The distributions of both RRV and BFV are likely to be altered by changes in rainfall, tidal inundation and land-use patterns, which will enable populations of mosquito vectors to establish in new areas. ${ }^{48}$ Under climate change scenarios, it has been predicted that dengue virus may eventually be found as far south as Sydney. ${ }^{49}$ Adaptive strategies for arbovirus control include improved modelling, early warning and control systems for mosquitoes, and ensuring the use of flyscreens in mosquito-prone areas.

\section{Foodborne diseases}

Foodborne diseases, particularly gastroenteritis, are relatively common in Australia. ${ }^{50}$ The symptoms of these diseases are usually mild, but can be serious in vulnerable people, occasionally causing death. ${ }^{51}$ The most common pathogens in food are Campylobacter and Salmonella and the notification rate is related to monthly temperature indicating a potential effect of climate change. ${ }^{52}$ In addition, Staphylococcus aureus is a common bacterium on skin that can grow in food, producing a powerful toxin that causes diarrhoea and vomiting. The growth and spread of these pathogens increase if the storage temperature of foods is not sufficiently cold, which is of vital importance in the event of interruptions to electricity supply. ${ }^{51}$ Adaptation strategies include better monitoring of foodborne diseases and increased awareness of health risks.

\section{Community and mental health}

Climate change may lead to adverse mental health outcomes. ${ }^{53}$ Natural disasters, such as storms, cyclones and prolonged drought have been shown to adversely affect mental health over time. ${ }^{54-57}$ In the future, Australia is likely to experience increases in droughts, which have been shown to be associated with an increased rate of suicide. ${ }^{57}$ Increases in individual mental health problems will have a follow-on effect for communities. Therefore, an important adaptive strategy is to increase community resilience to enable individuals to cope better with the conditions created by climate change.

A well-developed health care system in each community is another important adaptive strategy. Whether the health impacts are due to heat, violent weather, air pollution, infectious diseases or mental stress, efficient diagnostic and treatment services will make it possible to minimise the health impacts on the community. Such a system needs to ensure equitable access for all in the community, including the most vulnerable groups. A hotter climate may cause deterioration of medications and pharmaceutical therapies during storage, particularly in remote places with less developed health services. ${ }^{58}$

\section{Health co-benefits of mitigation and adaptation}

Table 1 summarises examples of health co-benefits that can be expected from mitigation and adaptation strategies as a response to climate change. There is a need for further research into the potential effects of different intervention strategies. For certain interventions, the value of health cobenefits may be even greater than the prevented climate change impacts.

\section{Conclusion}

The broad range of likely health impacts of climate change in NSW and Australia means that a variety of methods and strategies should be applied for mitigation and adaptation. Mitigation and adaptation can have direct co-benefits for the health of individuals and communities and should be encouraged. Early warning systems have a range of applications that can be used to assist communities to prepare for adverse conditions and the associated threats to health. Improving response teams and health systems (such as

Table 1. Examples of the main co-benefits of mitigation and adaptive strategies as a response to climate change

\begin{tabular}{|c|c|c|}
\hline Mitigation strategy & Adaptation strategy & Health co-benefits \\
\hline $\begin{array}{l}\text { Decreased fossil fuel } \\
\text { combustion }\end{array}$ & & $\begin{array}{l}\text { Cleaner, smog-free air and less respiratory } \\
\text { and cardiorespiratory diseases }\end{array}$ \\
\hline Improved public transport & & $\begin{array}{l}\text { More people walking (or cycling) to and } \\
\text { from stations, increases active transport, } \\
\text { promotes health and fitness and } \\
\text { reduces obesity }\end{array}$ \\
\hline \multirow{4}{*}{$\begin{array}{l}\text { Increased fruit and } \\
\text { vegetable consumption } \\
\text { and reduced meat } \\
\text { consumption }\end{array}$} & & $\begin{array}{l}\text { Less obesity, lower rates of cancer and } \\
\text { several other diseases }\end{array}$ \\
\hline & $\begin{array}{l}\text { Early warning systems for } \\
\text { weather extremes and disease } \\
\text { outbreaks }\end{array}$ & $\begin{array}{l}\text { Better health protection systems overall, } \\
\text { less impact in normal emergencies }\end{array}$ \\
\hline & Improved food handling practices & Reduced foodborne infections overall \\
\hline & $\begin{array}{l}\text { Improved programs to adapt } \\
\text { rural economies to a } \\
\text { changing climate }\end{array}$ & $\begin{array}{l}\text { Strengthened social capital and beneficial } \\
\text { effects on mental health }\end{array}$ \\
\hline
\end{tabular}


emergency services and health care practitioners) will enable a rapid response to emergency situations. The most important adaptive strategy that can be applied, however, is that of increased community awareness of climate change and the associated health risks. By understanding how environmental changes can result in adverse health impacts, we can plan to minimise exposure and health risks and to cope with the unavoidable effects of climate change.

\section{References}

1. CSIRO. Climate change in Australia. Technical report 2007. Melbourne: CSIRO and Australian Bureau of Meteorology; 2007.

2. IPCC. 2007: Climate Change 2007: Synthesis Report. Contribution of Working Groups I, II and III to the Fourth Assessment Report of the Intergovernmental Panel on Climate Change. IPCC, Geneva, Switzerland. Available from: http://www.ipcc.ch/ipccreports/ar4-syr.htm (Cited 02 December 2008.)

3. Preston BL, Jones RN. Climate change impacts on Australia and the benefits of early action to reduce global greenhouse gas emissions. Melbourne: CSIRO; 2006.

4. McMichael AJ, Powles JW, Butler CD, Uauy R. Food, livestock production, energy, climate change, and health. Lancet 2007; 370: 1253-63. doi:10.1016/S0140-6736(07)61256-2

5. Mukheibir P, Ziervogel G. Developing a Municipal Adaptation Plan for climate change: the city of Cape Town. Environ Urban 2007; 19: 143-58. doi:10.1177/0956247807076912

6. Kjellstrom T, van Kerkhoff L, Bammer G, McMichael AJ. Comparative assessment of transport risks - how it can contribute to health impact assessment of transport policies. Bull World Health Organ 2003; 81: 451-7.

7. McMichael AJ, Campbell-Lendrum D, Kovats S, Edwards S, Wilkinson P, Wilson T et al. Global climate change. In: Ezzati M, Lopez AD, Rodgers A, Murrgay CJL, editors. Comparative quantification of health risks: global regional burden of diseases due to selected major risk factors. Vol. 2. Chapter 20. Geneva: World Health Organization; 2004. pp. 1543-649.

8. Patz JA, Gibbs HK, Foley JA, Rogers JV, Smith KR. Climate change and global health: quantifying a growing ethical crisis. EcoHealth 2007; 4: 397-405. doi:10.1007/s10393-007-0141-1

9. Bambrick H, Dear K, Woodruff R, Hanigan I, McMichael AJ. The impact of climate change on three health outcomes: Temperature-related mortality and hospitalisations, salmonellosis and other bacterial gastroenteritis, and population at risk from dengue. Commissioned report for the Garnaut Climate Change Review. Canberra: The Australian National University; 2007.

10. Kirch W, Menne B, Bertollini R. Extreme weather events and public health responses. Berlin: Springer; 2005.

11. McMichael AJ, Woodruff RE, Whetton P, Hennessy K, Nicholls N, Hales S et al. Human health and climate change in Oceania: a risk assessment 2002. Canberra: Commonwealth Department of Health and Ageing; 2003.

12. Cretikos MA, Merritt TD, Main K, Eastwood K, Winn L, Moran L et al. Mitigating the health impacts of natural disaster - the June 2007 long-weekend storm in the Hunter region of New South Wales. Med J Aust 2007; 187: 670-3.
13. McMichael AJ, Weaver HJ, Berry H, Beggs PJ, Currie B, Higgins J et al. National Adaptation Research Plan (Human Health). Commissioned report by the Australian Department of Health and Ageing, 2008.

14. Poumadere M, Mays C, Le Mer S, Blong R. The 2003 heat wave in France: Dangerous climate change here and now. Risk Anal 2005; 25: 1483-94. doi:10.1111/j.15396924.2005.00694.x

15. Kovats RS, Hajat $\mathrm{S}$. Heat stress and public health: a critical review. Ann Rev Public Health 2008; 29: 41-51. doi:10.1146/annurev.publhealth.29.020907.090843

16. Haines A, Kovats RS, Campbell-Lendrum D, Corvalan C. Climate change and human health: impacts, vulnerability and mitigation. Lancet 2006; 367(9528): 2101-9. doi:10.1016/S0140-6736(06)68933-2

17. Guest CS, Willson K, Woodward AJ, Hennessy K, Kalkstein LS, Skinner C et al. Climate and mortality in Australia: retrospective study, 1979-1990, and predicted impacts in five major cities in 2030. Clim Res 1999; 13: 1-15. doi:10.3354/cr013001

18. Vaneckova P, Hart MA, Beggs PJ, de Dear RJ. Synoptic analysis of heat-related mortality in Sydney, Australia, 1993-2001. Int J Biometeorol 2008; 52(6): 439-51. doi:10.1007/s00484-007-0138-z

19. Bi P, Parton KA, Wang J, Donald K. Temperature and direct effects on population health in Brisbane, 1986-1995. J Environ Health 2008; 70: 48-53.

20. Nicholls N, Skinner C, Loughnan M, Tapper N. A simple heat alert system for Melbourne, Australia. Int J Biometeorol 2008; 52: 375-84. doi:10.1007/s00484-007-0132-5

21. Nitschke M, Tucker GR, Bi P. Morbidity and mortality during heatwaves in metropolitan Adelaide. Med J Aust 2007; 187: $662-5$.

22. Hennessy K, Lucas C, Nicholls N, Bathols J, Suppiah R, Ricketts J. Climate change impacts on fire-weather in southeast Australia. Melbourne: CSIRO; 2005.

23. Taylor NAS. Challenges to temperature regulation when working in hot environments. Ind Health 2006; 44: 331-44. doi:10.2486/indhealth.44.331

24. Parsons K. Human thermal environments. 2nd ed. London: Taylor and Francis; 2003.

25. Budd GM, Brotherhood JR, Hendrie AL, Jeffery SE, Beasley FA, Costin BP et al. Project Aquarius 10. Effects of work, weather and fire on the energy expenditure, strain and productivity of men suppressing wildland fires. Int J Wildland Fire 1997; 7: 167-80. doi:10.1071/WF9970167

26. Donoghue A, Sinclair M, Bates G. Heat exhaustion in a deep underground metalliferous mine. Occup Environ Med 2000; 57: 165-74. doi:10.1136/oem.57.3.165

27. Miller VS, Bates GP. The thermal work limit is a simple reliable heat index for the protection of workers in thermally stressful environments. Ann Occup Hyg 2007; 51: 553-61. doi:10.1093/annhyg/mem035

28. Carter A, Muller R. Hydration knowledge, behaviours and status of staff at the residential camp of a fly-in/fly-out minerals extraction and processing operation in tropical North-Eastern Australia. Ind Health 2007; 45: 579-89. doi:10.2486/indhealth.45.579 
29. Muller R, Carter A, Williamson A. Epidemiological diagnosis of occupational fatigue in a fly-in/fly-out operation of the mineral industry. Ann Occup Hyg 2008; 52: 63-72. doi:10.1093/annhyg/mem058

30. Gun RT, Budd GM. Effects of thermal, personal and behavioural factors on the physiological strain, thermal comfort and productivity of Australian shearers in hot weather. Ergonomics 1995; 38: 1368-84. doi:10.1080/00140139508925195

31. Taylor NAS, Caldwell JN. The impact of protective helmets on physiological strain and cognitive function during horseback mustering. Sydney: Meat and Livestock Australia; 2007.

32. Budd GM. Wet-bulb globe temperature (WBGT) - its history and limitations. J Sci Med Sport 2008; 11: 20-32. doi:10.1016/j.jsams.2007.07.003

33. International Standards Organization. Hot environments Estimation of the heat stress on working man, based on the WBGT-index (wet bulb globe temperature). ISO Standard 7243. Geneva: International Standards Organization; 1989.

34. Kjellstrom T. Climate change, heat exposure and labour productivity. Epidemiology 2000; 11: S144.

35. Kjellstrom T, Dirks KN. Heat stress and ability to work in the context of climate change. Proceedings of the International Thermal Physiology Symposium; 2001 Sep 2-6; Wollongong: University of Wollongong; 2001. Available from: http://www.apps.org.au/Proceedings/32(2)Suppl.1/23P/ 23P.pdf (Cited 11 December 2008.)

36. American Academy of Pediatrics, Committee on Sports Medicine and Fitness. Climatic heat stress and the exercising child and adolescent. Pediatrics 2000; 106: 158-9. doi:10.1542/peds.106.1.158

37. Thomas KM, Charron DF, Waltner-Toews D, Schuster C, Maarouf AR, Holt JD. A role of high impact weather events in waterborne disease outbreaks in Canada, 1975-2001. Int $J$ Environ Health Res 2006; 16(3): 167-80. doi:10.1080/09603120600641326

38. Hunter PR. Climate change and waterborne and vector-borne disease. J Appl Microbiol 2003; 94: S37-46. doi:10.1046/j.1365-2672.94.s1.5.x

39. Ferguson CM, Croke BFW, Beatson PJ, Ashbolt NJ, Deere DA. Development of a process-based model to predict pathogen budgets for the Sydney drinking water catchment. $J$ Water Health 2007; 5: 187-208. doi:10.2166/wh.2006.050

40. Kjellstrom T, Neller A, Simpson R. Air pollution and its health impacts: the changing panorama. Med J Aust 2002; 177: 604-8.

41. Simpson RW, Chan YC, Hansen CA, Jalaludin B, Morgan G, Barnett AG et al. Several references on epidemiological studies of air pollution in Australia 2008. Available from: http://research.usc.edu.au/vital/access/manager/Repository? expert $=$ creator $\% 3 \mathrm{a} \% 22$ Simpson $\% 2 \mathrm{c}+\mathrm{R}+\mathrm{W} \% 22$ (Cited 02 December 2008.)

42. Duffy BL, Nelson PF, Ye Y, Weeks IA. Speciated hydrocarbon profiles and calculated reactivities of exhaust and evaporative emissions from 82 in-use light-duty Australian vehicles. Atmos Environ 1999; 33: 291-307. doi:10.1016/S13522310(98)00163-0

43. Dear K, Ranmuthugala G, Kjellstrom T, Skinner C, Hanigan I. Effects of temperature and ozone on daily mortality during the
August 2003 heat wave in France. Arch Environ Occup Health 2005; 60: 205-12. doi:10.3200/AEOH.60.4.205-212

44. Ren C, Tong S. Temperature modifies the health effects of particulate matter in Brisbane, Australia. Int J Biometeorol 2006; 51: 87-96. doi:10.1007/s00484-006-0054-7

45. Beggs PJ. Impacts of climate change on aeroallergens: past and future. Clin Exp Allergy 2004; 34: 1507-13. doi:10.1111/j.1365-2222.2004.02061.x

46. Russell RC. Mosquito-borne arboviruses in Australia: the current scene and implications of climate change for human health. Int J Parasitol 1998; 28(6): 955-69. doi:10.1016/S0020-7519(98)00053-8

47. Sutherst RW. Implications of global change and climate variability for vector-borne diseases: generic approaches to impact assessments. Int J Parasitol 1998; 28: 935-45. doi:10.1016/S0020-7519(98)00056-3

48. Jacups SP, Whelan PI, Currie BJ. Ross River virus and Barmah Forest virus infections: a review of history, ecology and predictive models, with implications for tropical northern Australia. Vector Borne Zoonotic Dis 2008; 8(2): 283-97. doi:10.1089/vbz.2007.0152

49. Hales S, de Wet N, Maindonald J, Woodward A. Potential effect of population and climate changes on global distribution of dengue fever: an empirical model. Lancet 2002; 360(9336): 830-4. doi:10.1016/S0140-6736(02)09964-6

50. Hall GV, Kirk MD, Ashbolt R, Stafford R, Lalor K. OzFoodNet Working Group. Frequency of infectious gastrointestinal illness in Australia, 2002: regional, seasonal and demographic variation. Epidemiol Infect 2006; 134: 111-8. doi:10.1017/S0950268805004656

51. Hall GV, D'Souza RM, Kirk MD. Foodborne disease in the new millennium: out of the frying pan and into the fire? Med J Aust 2002; 177: 614-8.

52. D'Souza RM, Becker NG, Hall G, Moodie KBA. Does temperature affect foodborne disease? Epidemiology 2004; 15: 86-92. doi:10.1097/01.ede.0000101021.03453.3e

53. Berry HL, Kelly BJ, Hanigan IC, Coates JH, McMichael AJ, Welsh JA et al. Rural mental health impacts of climate change. Commissioned report for the Garnaut Climate Change Review. Canberra: The Australian National University; 2008.

54. Raphael B. When disaster strikes: How individuals and communities cope with catastrophe. New York: Basic Books; 1986.

55. McFarlane A, Clayer J, Brookless C. Psychiatric morbidity following a natural disaster: an Australian bushfire. Soc Psychiatry Psychiatr Epidemiol 1997; 32(5): 261-8. doi:10.1007/BF00789038

56. Sartore G, Hoolahan B, Tonna A, Kelly B, Stain H. Wisdom from the drought: Recommendations from a consultative conference. Aust J Rural Health 2005; 13(5): 315-20. doi:10.1111/j.1440-1584.2005.00723.x

57. Nicholls N, Butlere CD, Hanigan I. Inter-annual rainfall variations and suicide in New South Wales, Australia, 1964-2001. Int J Biometeorol 2006; 50: 139-43. doi:10.1007/s00484-005-0002-y

58. Beggs PJ. Impacts of climate and climate change on medications and human health. Aust N Z J Public Health 2000; 24: 630-2. doi:10.1111/j.1467-842X.2000.tb00531.x 